\title{
The effective role of work environment and its influence on managerial innovation
}

\author{
Salah A. Alabduljader ${ }^{a^{*}}$
}

${ }^{a}$ Faculty Member of Management and Marketing, Department Business Administration College, Kuwait University, Kuwait

\begin{tabular}{l}
\hline C H R O N I C L E \\
\hline Article history: \\
Received: September 19, 2018 \\
Received in revised format: Octo- \\
ber 2, 2018 \\
Accepted: October 19, 2018 \\
Available online: \\
October 19, 2018 \\
\hline Keywords: \\
Managerial innovation \\
Work environment \\
Employee appraisal
\end{tabular}

\section{Introduction}

Since the start of the 21st Century, innovation has been one of the major parts of modern and monetary improvements approaches in the West. Political plans of the most developed economies, dependably, incorporate programs expected to enhance innovative capacities of organizations with a specific goal to make diverse items and administrations (Sánchez et al., 2011). To some degree, this institutional pattern has been prodded by the customary scholastic help of innovation, as a key ability for the support of organizations. Awamleh (1994) in the twentieth century pointed out the significance of development as a driver for monetary development. Afterwards, Nurmandi and Kim (2015) recommended that the aggressiveness of countries relied on the capacity of an industry to develop and enhance, and the organizations accomplish upper hand through this advancement. In this way development has ended up being vital at the organizational level and also national level. The hypothetical and observational examination gathered in the last couple of decades about the effect of development administration on execution, have brought just a couple of definitive outcomes, particularly at the single organization level (Chang, 2016).

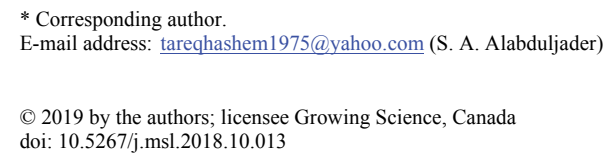

\begin{abstract}
Trying to create an innovative organization means to have employees who are innovative, within vironment on managerial innovation within the insurance sector in Kuwait. A quantitative tool, selfadministered questionnaire, was adopted and distributed among 165 managers who worked for 21 insurance companies in Kuwait. The results indicate that among the chosen variables representing the dimensions of the work environment, the most influential dimension was facilities. This reveals that it was the influence of facilities that provided a healthy work environment for the employees that organizations should pay extra attention to certain factors of employee appraisal such as incentives, appreciation and recognition, that may, in turn, help increase the degree of managerial innovation. In addition, it is suggested to examine the influence of work environment on the leaders' ethical orientations within the insurance sector in Kuwait.
\end{abstract}

C 2019 by the authors; licensee Growing Science, Canada 


\section{Problem Statement}

With the different technical and intellectual developments in the world, organizations began to support individuals who are able to come up with new ideas and innovative approaches to manage and get things accomplished. Barsh et al. (2008) argued that innovation is crucial in organization and it is even more crucial when it comes to managers and leaders, for this reason, an organization should support innovation among mangers and leaders. Sánchez et al. (2011) stated that innovation among managers is driven by strategies and plans of the organizations. If the staff had the proper type of strategic planning, then innovation would be one of the most noticeable aspects within the organizations.

On the other hand, Dul and Ceylan (2011) saw the work environment as the first and the most effective driver of organization's innovation. While Serrat (2017) stated that a healthy work environment has the ability to induce innovation and creativity among employees and leaders in an organization. Szobiová (2015) and Ying (2006) agreed on the fact that a good work environment and a well-built workplace can be considered as a driver to a more innovative and creative staff.

Based on the above argument, the current study aimed at examining the role of work environment in supporting and developing managerial innovation among middle management and leaders of insurance sector in Kuwait. In order to have the ability to measure the influence of the work place on managerial creativity; the researcher employed variables from a study by Zúñiga et al. (2015) which included work environment (Facilities, High Management Support, Teamwork, Safety and Security, Work Stressors and Recognition and Appreciation). Fig. 1 describes the relationship between the variables:

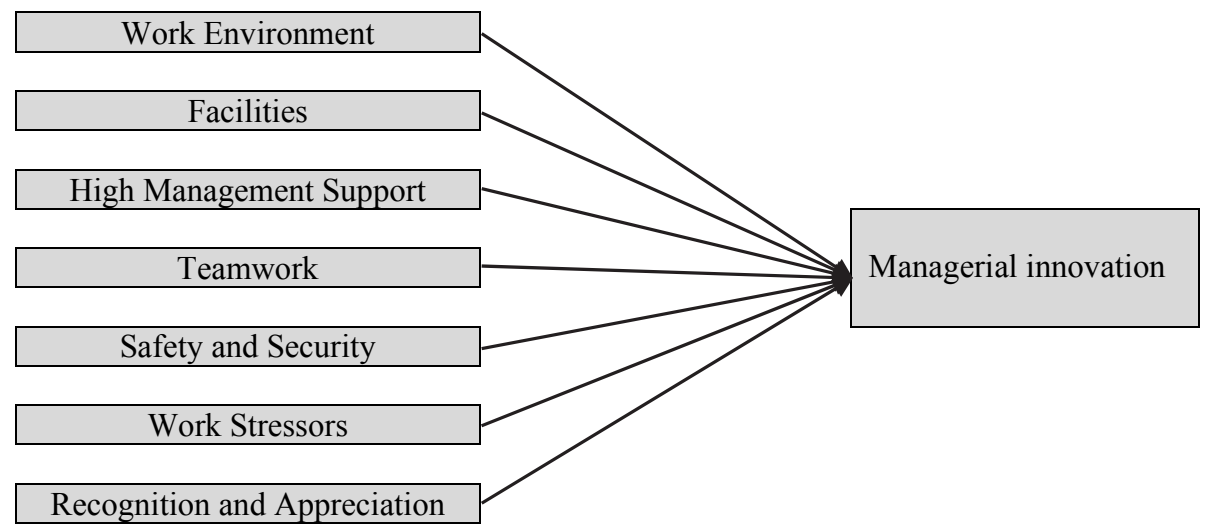

Fig. 1. Study Model (Zúñiga et al., 2015)

\section{Questions and Hypotheses}

The current study aims to answer the following questions:

What is the role of work environment in developing management innovation within insurance companies in Kuwait?

From the question above, researcher is able to develop a set of hypotheses:

\section{H: Work environment has a positive effect on managerial innovations.}

$\mathrm{H}_{\mathrm{a}}$ : Facilities have a positive effect on managerial innovations.

$\mathrm{H}_{\mathbf{b}}$ : Better management support has a positive effect on managerial innovations.

$\mathrm{H}_{\mathbf{c}}$ : Teamwork has a positive effect on managerial innovations.

$\mathrm{H}_{\mathbf{d}}$ : Safety and security have positive effects on managerial innovations.

$\mathrm{H}_{\mathrm{e}}$ : Work stressors have a positive effect on managerial innovations.

$\mathrm{H}_{\mathbf{f}}$ : Recognition and appreciation has a positive effect on managerial innovations. 


\section{Literature Reviews}

The following section puts into perspective some of the recent studies regarding the variables that appeared in the model and aimed at highlighting the recent views and standpoints within the field of interest.

\subsection{Work Environment}

Individuals are extremely cheerful to have a vocation, however, a considerable number of them, never feel that their working environment is actually their second homes, and they have several opportunities there. This frequently drives them to feel compelled to adjust to the awkward conditions. According to Al-Omari and Okasheh (2017) employees' working environment/condition is a key determinant of the nature of their work and their level of efficiency. How well the work environment draws in representative affects their abilities and their level of inspiration to perform. In the world of progressive rivalry/competition among organizations and even among nations; the efficient execution of HR is required. The fundamental objective of the work for anyone is not just remuneration, but to achieve success and reputation as well. Employees' performances are influenced/impacted by several factors such as motivation, workplace environment and leadership in the office, etc.

\subsubsection{Definition of Work Environment}

According to Foldspang et al. (2014) a work environment is defined as the nature of the physical and psychological characteristics of a working place in which the employees spend most of their working hours. On the other hand, Stanely (2016. P.1) defined work environment as "those contextual characteristics that influence creative behaviors such as characteristics of the job, work setting, and relationships with co-workers and supervisors."

Many researchers have defined the characteristics of a good work environment; Gilbride et al. (2003) noted that a healthy work environment contains three major specifications which are work culture, job description and the employers' experience and support. On the other hand, Hawley and Barnard (2005) stated that facilities, psychology and physical aspects are the main specifications of a healthy work environment but support from peer workers and management is the most important. Researcher of current study has chosen the set of variables employed in a study by Zúñiga et al. (2015) with some alterations that matched the study; those variables included:

\subsubsection{Facilities}

Ajala (2012) stated that facilities within the work environment include all the basic needs that an employee may need in a work place, this includes rest rooms, toilets, cafeteria, ventilated offices and a wide space for movement. Stansfeld and Candy (2006) referred to the facilities as all the basic necessities that enable employees to go on with their work. These include proper seating, space, ventilation and accommodation.

\subsubsection{High Management Support}

Kroth et al. (2007) saw that management support is one of the most important aspects of a healthy work environment. Authors stated that the management support is considered to be the main psychological specification of a good work environment, as it has the ability to influence the employees' performance, and appreciations of the organizations in general: the management in particular (Shobe, 2018).

\subsubsection{Teamwork}

Teamwork is critical. If there appears to be a lack of team work, then the work environment will be negatively influenced. Teamwork influences the productivity of employees and the way leaders and managers lead the whole staff. It is important to preserve a good level of teamwork that enables employees to work properly and raise their performances (Sanyal \& Hisam, 2018). 


\subsubsection{Safety and Security}

De Spiegelaere et al. (2014) spoke of the immense importance of job security on innovation and its role in increasing the productivity within the work place. Job security refers to the secure feelings that an employee holds towards their job; it includes the positive feelings and the idea that they will not to lose their job, if they do their duties, properly. As for the safety in the work place, it refers to the basics of a safe environment for individuals like fire escapes, proper exits and other standards of safety (Dawson \& Zanko, 2009; Pot, 2011).

\subsubsection{Work Stressors}

According to Bryson and Dale-Olsen (2009) stress in the work place is among the most influential factors that may decrease individuals' ability to perform better and negatively influence their productivity. An organization with a healthy work environment should be able to manage work stress in a professional way in order to avoid any negative influence on employees which may hinder their innovative thinking (Bannon, 2010).

\subsubsection{Recognition and Appreciation}

According to Zúñiga et al. (2015) recognition and appreciation are among the factors that give a positive feeling in a work place especially if it came from the management. Appreciated employees are always more motivated, happier and encouraged to do their job compared to the ones whose management is always absent. A healthy work environment for employees resembles the appreciation and recognition of their management and leadership of the good deeds and performance that they put in (Garr. 2012).

\subsection{Managerial Innovation}

As a start, Damanpour and Aravind (2012, p.425) innovation is defined as 'the generation (development) or adoption (use) of new ideas or behaviors.' Nieves and Osorio (2018) saw that through innovation within an organization, there could be a space for product development, service development, and better decision making process, more enhanced managerial plans and strategies, in addition to good practices and hierarchal enhancements. Innovation in organization has been driven by many factors which enhanced its appearance within the field of management. These factors included technological developments, organizational enhancements, awareness at managerial level and employee level, in addition to the fierce competition that organizations face within the market (Lopes et al., 2017).

\subsubsection{Definition of Innovation in Management}

According to Damanpour and Aravind (2012, p.424) managerial innovation is defined as "new organizational structures, administrative systems, management practices, processes, and techniques that could create value for the organization". Precedents of this sort of innovation as Nieves and Osorio (2018) noted incorporating total quality management (TQM), just-in-time, quality circle, cost counting, 360 degree feedback, and divisional (M-form) structure for improving performance evaluation. More consideration is progressively being paid by the business and professional press to the vital job of managerial innovation in creating techniques for development, encouraging authoritative change and restoration, and empowering nonstop execution (Rosario et al., 2013). This consideration is late, as a company's prospect to contend and maintain execution requires nonstop innovation - the presentation of various sorts of innovations after some time. This capacity is subject to an association's capacity to utilize new administration thoughts for altering and enhancing its structure and procedures to empower vital reestablishment and authoritative change (Lopes et al., 2017).

\subsubsection{Drivers of Managerial Innovation}

In an organization, the nature of the culture that is found within the internal environment, in addition to the level of understanding towards the external environment are among the main supports and motivators 
of managerial innovation, as mentioned by Zlatanović and Mulej (2015). Other drivers that may influence the degree of innovation within the managerial system in organizations may also be involved (Dufays, 2018; Soto-Acosta \& Martinez-Conesa, 2018; Lerro et al., 2014; Smith \& Tushman, 2005; BuenecheaElberdin et al., 2018; Su \& Baird, 2017; Caniëls, 2008) including the following,

- Strategies and structures followed in an organization,

- Internal procedures and practices,

- Managerial support, this involves the support of higher management,

- $\quad$ The use of ICT (information and communications technologies),

- Talents and skills within the staff of the organization, this involves managers, leaders and employees,

- A good work environment that enables the human force to act in accordance with the organizational mission and vision.

\subsubsection{Relationship between Work Environment and Innovative Management}

Work environment was seen to be one of the factors that influence managerial innovation. As it was argued within the previous sections; when a member enjoys a healthy work place/environment, it would be easier and more likely for them to perform well. In a study by Ismaeil (2014), he indicated that there appeared an influence of hierarchal system, training, incentives, and work circumstance on the managerial innovation among employees but it appeared that technology did not have an influence on their innovative management. The study recommended to decrease the loss in the experiences, skills and talents through increasing the appraisals of the employees and achieve job satisfaction within the university. Another study by Al-Mshoot (2011) examined the impact of work environment on managerial innovation within Saad Al-Abdullah Academy for Security Sciences in Kuwait state. The results indicated an influence of work environment attributed to higher management support; and the fact that, when an employee, regardless of their position, works in a healthy environment, it can support their innovative skills and encourage them perform well. A study by Dul and Ceylan (2011) on the influence of work environment on creativity and innovation in management and indicated that creative work environment could enhance creative performance.

\section{Methods and Methodology}

This section presents the methodological aspects which were employed in order to answer the main questions of the study. It includes the methodology, tool of study, sample and statistical processes.

\subsection{Methodological Approach}

Quantitative methodology was chosen by the researcher to collect the needed data for the study. Quantitative approach was defined by Wiersma and Jurs (2005. P.15) as 'a research methods dealing with numbers and anything that is measurable in a systematic way of investigation of phenomena and their relationships.'

\subsection{Tool of Study}

One of the tools of quantitative methodology is the questionnaire. A self-administered questionnaire was developed to collect data from the sample of the study. The tool appeared in two main sections; the first collected the demographic variables of the study including gender, age, experience, education and position, while the second section consisted of statements related to the variables of the study.

\subsection{Population and Sample}

From a total of twenty-one insurance companies in Kuwait, the researcher has chosen a sample of two hundred leaders, department managers and middle managers to form the sample. After the process of 
distribution, the researcher was able to retrieve a total of hundred and sixty five properly filled questionnaires which formed eighty two percent of the initial sample, making it as statistically acceptable.

\subsection{Data Screening and Processing}

The data screening and processing was tackled using the statistical package of social sciences (SPSS). The study uses simple and multiple regression as well as descriptive analysis on the raw data of the study:

\subsection{Ethics of Research}

In order to guarantee the best research results from the study, the researcher employed ethics appeared in BERA (2011), those ethics included responsibility towards the participants, academic society and sponsor of the research.

\section{Results and Discussion}

This section presents the statistical results of the raw data processing through SPSS. The results are shown in two parts; the demographics and the analysis of the questionnaire.

\subsection{Demographic Variables}

Table 1

Sample distribution according to gender

\begin{tabular}{llcccc}
\hline & & Frequency & Percent & Valid Percent & Cumulative Percent \\
\hline \multirow{3}{*}{ Valid } & Male & 66 & 40.0 & 40.0 & 40.0 \\
& Female & 99 & 60.0 & 60.0 & 100.0 \\
\cline { 2 - 6 } & Total & 165 & 100.0 & 100.0 & \\
\hline
\end{tabular}

According to Table 1, the analysis shows that higher percentage of the sample is associated with females with a frequency of $99(60 \%)$ and the rest of the total sample are male $(40 \%)$. In Table 2 , it can be seen that $38.8 \%$ of the sample are individuals within the age range of $29-35$, indicating the involvement of the young talent within the insurance sector in Kuwait.

Table 2

Sample distribution according to age

\begin{tabular}{cccccc}
\hline & & Frequency & Percent & Valid Percent & Cumulative Percent \\
\hline Valid & $22-28$ & 26 & 15.8 & 15.8 & 15.8 \\
& $29-35$ & 64 & 38.8 & 38.8 & 54.5 \\
& $36-42$ & 47 & 28.5 & 28.5 & 83.0 \\
& +43 & 28 & 17.0 & 17.0 & 100.0 \\
\cline { 2 - 6 } & Total & 165 & 100.0 & 100.0 & \\
\hline
\end{tabular}

Table 3

Sample distribution according to education

\begin{tabular}{llcccc}
\hline & & Frequency & Percent & Valid Percent & Cumulative Percent \\
\hline Valid & Bachelor & 19 & 11.5 & 11.5 & 11.5 \\
& MA & 116 & 70.3 & 70.3 & 81.8 \\
& PhD & 30 & 18.2 & 18.2 & 100.0 \\
\cline { 2 - 6 } & Total & 165 & 100.0 & 100.0 & \\
\hline
\end{tabular}

In Table 3, it appears that the postgraduates with a master's degree $(70.3 \%)$ are more as compared to the postgraduates with a $\mathrm{PhD}$, constituting about $18.2 \%$ of the total. This indicates the level of education of the managers and leaders in the insurance sector in Kuwait. According to Table 4, which examines the position of participants, it shows that $83.6 \%$ of participants are from the middle management which is the focus of the current study. Table 5 shows the sample characteristics according to experience; it appears that $25.5 \%$ of participants have an experience within the managerial field that ranges between $6-7$ years. In the $2^{\text {nd }}$ rank came individuals who had an experience of $24.2 \%$ who have been recently promoted and had an experience in management up to 1 year. 
Table 4

Sample distribution according to position

\begin{tabular}{llcccc}
\hline & & Frequency & Percent & Valid Percent & Cumulative Percent \\
\hline Valid & Employee & 8 & 4.8 & 4.8 & 4.8 \\
& Team Leader & 5 & 3.0 & 3.0 & 7.9 \\
& Officer & 14 & 8.5 & 8.5 & 16.4 \\
& Middle Management & 138 & 83.6 & 83.6 & 100.0 \\
\cline { 2 - 6 } & Total & 165 & 100.0 & 100.0 & \\
\hline
\end{tabular}

Table 5

Sample distribution according to experience

\begin{tabular}{llcccc}
\hline & & Frequency & Percent & Valid Percent & Cumulative Percent \\
\hline Valid & $0-1$ & 40 & 24.2 & 24.2 & 24.2 \\
& $2-3$ & 25 & 15.2 & 15.2 & 39.4 \\
& $4-5$ & 25 & 15.2 & 15.2 & 54.5 \\
& $6-7$ & 42 & 25.5 & 25.5 & 80.0 \\
& +8 & 33 & 20.0 & 20.0 & 100.0 \\
\cline { 2 - 6 } & Total & 165 & 100.0 & 100.0 & \\
\hline
\end{tabular}

\subsection{Questionnaire Analysis}

\section{Table 6}

Questionnaire statements analysis

\begin{tabular}{|c|c|c|c|c|c|}
\hline & $\mathrm{N}$ & Min & Max & Mean & Std. Deviation \\
\hline \multicolumn{6}{|l|}{ Managerial Innovation } \\
\hline I always look for new ways to manage my team & 165 & 1.0 & 5.0 & 3.994 & .9532 \\
\hline I do not manage in a conventional way & 165 & 1.0 & 5.0 & 3.970 & .9267 \\
\hline New ideas and ways are always good and are welcomed & 165 & 1.0 & 5.0 & 3.764 & 1.1785 \\
\hline Managing innovatively creates long lasting advantages for the organization & 165 & 1.0 & 5.0 & 3.861 & 1.0055 \\
\hline When I manage my team innovatively I skip the pitfalls of conventional management & 165 & 1.0 & 5.0 & 3.691 & 1.0396 \\
\hline Innovation is based on a novel principle that challenges management's orthodoxy & 165 & 1.0 & 5.0 & 3.709 & 1.0593 \\
\hline An innovative manager develops skills and talents of employees & 165 & 1.0 & 5.0 & 3.727 & 1.0498 \\
\hline Managing innovatively can influence ethical aspects of management & 165 & 1.0 & 5.0 & 3.727 & 1.0841 \\
\hline \multicolumn{6}{|l|}{ Work Environment } \\
\hline \multicolumn{6}{|l|}{ Facilities } \\
\hline I always find what I need in the department & 165 & 1.0 & 5.0 & 3.564 & 1.0948 \\
\hline The department I manage is well prepared & 165 & 1.0 & 5.0 & 3.612 & 1.1076 \\
\hline The organization enjoys a good level of infrastructure & 165 & 1.0 & 5.0 & 3.539 & 1.0271 \\
\hline I have all I need to support me as a manager & 165 & 1.0 & 5.0 & 3.685 & .9803 \\
\hline \multicolumn{6}{|l|}{ Management Support } \\
\hline Higher management always follow the department & 165 & 1.0 & 5.0 & 3.764 & .9993 \\
\hline I always meet with the higher management to discuss recent development & 165 & 1.0 & 5.0 & 3.582 & 1.0596 \\
\hline The higher management is always absent & 165 & 1.0 & 5.0 & 3.600 & 1.0638 \\
\hline Higher management support is crucial for managing departments & 165 & 1.0 & 5.0 & 3.582 & 1.0880 \\
\hline \multicolumn{6}{|l|}{ Teamwork } \\
\hline Employees are chosen based on their talents and skills & 165 & 1.0 & 5.0 & 3.127 & 1.2305 \\
\hline I have the needed level of understanding with my team & 165 & 1.0 & 5.0 & 3.297 & 1.2983 \\
\hline Teamwork is important when it comes to management & 165 & 1.0 & 5.0 & 3.255 & 1.1669 \\
\hline We manage and lead as one family in the department & 165 & 1.0 & 5.0 & 3.230 & 1.1456 \\
\hline My team gives me the space to be innovative & 165 & 1.0 & 5.0 & 3.242 & 1.3577 \\
\hline \multicolumn{6}{|l|}{ Safety and Security } \\
\hline I have a good level of security in my job & 165 & 1.0 & 5.0 & 3.388 & 1.0335 \\
\hline I don't have any doubts about my position & 165 & 1.0 & 5.0 & 3.430 & 1.0776 \\
\hline My work place is safe and secured & 165 & 1.0 & 5.0 & 3.085 & 1.2118 \\
\hline I don't mind spending more hours at work & 165 & 1.0 & 5.0 & 3.345 & 1.1024 \\
\hline \multicolumn{6}{|l|}{ Work Stressors } \\
\hline I always find innovative ways to take the load of me and my team & 165 & 1.0 & 5.0 & 3.630 & 1.0776 \\
\hline The level of talents and skills in the department allows me to manage innovatively & 165 & 1.0 & 5.0 & 3.636 & 1.0006 \\
\hline When under stress, my performance drops down & 165 & 1.0 & 5.0 & 3.703 & 1.0014 \\
\hline I have the needed skills in the department to count on them & 165 & 1.0 & 5.0 & 3.891 & .9878 \\
\hline With the way we manage, we are never under pressure or feel stressful & 165 & 1.0 & 5.0 & 3.485 & 1.1021 \\
\hline \multicolumn{6}{|l|}{ Recognition and Appreciation } \\
\hline Higher management always notices the good things & 165 & 1.0 & 5.0 & 3.667 & 1.0320 \\
\hline I have been promoted to my position through the natural way & 165 & 1.0 & 5.0 & 3.691 & 1.0628 \\
\hline My higher management recognizes my efforts & 165 & 1.0 & 5.0 & 3.630 & .9641 \\
\hline No matter what I do, no one sees & 165 & 1.0 & 5.0 & 3.509 & 1.0967 \\
\hline I am appreciated in my organization & 165 & 1.0 & 5.0 & 3.430 & 1.1328 \\
\hline Valid N (list wise) & 165 & & & & \\
\hline
\end{tabular}


In Table 6, it can be seen that respondents have positive attitudes towards the statements in the questionnaire; this can be inferred through the mean of the statements which score higher than 3.00 indicating the results as good. From the analysis, it can be inferred that the most positively answered statement was the first statement: "I always look for new ways to manage my team", which scored a mean of 3.994. On the other hand, the least answered statement in a positive way, appeared to be the twenty fourth statement: "My work place is safe and secured", which scored as low as 3.085. Examining the results of the questionnaire in Table 7, it was seen that there was a positive attitude from participants towards the above variables. This can be inferred through the mean of the paragraphs which scored higher than 3.00, indicating it as good.

Table 7

Descriptive variables

\begin{tabular}{lccccc}
\hline & $\mathrm{N}$ & Minimum & Maximum & Mean & Std. Deviation \\
\hline Innovation & 165 & 1.25 & 5.00 & 3.8053 & .87198 \\
Facilities & 165 & 1.50 & 5.00 & 3.6000 & .90088 \\
support & 165 & 1.00 & 5.00 & 3.6318 & .91962 \\
Teamwork & 165 & 1.00 & 5.00 & 3.2303 & 1.02019 \\
Safety & 165 & 1.00 & 5.00 & 3.3121 & .97897 \\
Stressors & 165 & 1.00 & 5.00 & 3.6691 & .89814 \\
Recognition & 165 & 1.40 & 5.00 & 3.5855 & .84002 \\
\hline Valid N (list wise) & 165 & & & & \\
\hline
\end{tabular}

\subsection{Reliability Test}

A reliability test was carried out using Cronbachs' Alpha. The result shows a value of 0.975 for the all items. Alpha for each variable is greater than accepted percent 0.60 , which is a reasonable value indicating the tool consistency that enhanced its use for the study.

\subsection{Hypotheses Testing}

\subsubsection{Main Hypothesis}

\section{H: Work environment has a positive effect on managerial innovation}

\section{Table 8}

$\mathrm{H}_{1}$ Model Summary

\begin{tabular}{ccccc}
\hline Model & $\mathrm{R}$ & R Square & Adjusted R Square & Std. Error of the Estimate \\
\hline 1 & $.869^{\mathrm{a}}$ & .756 & .746 & .43927 \\
\hline
\end{tabular}

\section{Table 9}

$\mathrm{H}_{1}$ ANOVA $^{\mathrm{a}}$

\begin{tabular}{clccccc}
\hline \multicolumn{2}{c}{ Model } & Sum of Squares & df & Mean Square & F & Sig. \\
\hline \multirow{2}{*}{1} & Regression & 94.211 & 6 & 15.702 & 81.374 & $.000^{\mathrm{b}}$ \\
\cline { 2 - 7 } & Residual & 30.487 & 158 & .193 & & \\
\cline { 2 - 7 } & Total & 124.698 & 164 & & & \\
\hline
\end{tabular}

Table 10

$\mathrm{H}_{1}$ Coefficients $^{\mathrm{a}}$

\begin{tabular}{|c|c|c|c|c|c|c|}
\hline \multirow{2}{*}{\multicolumn{2}{|c|}{ Model }} & \multicolumn{2}{|c|}{ Unstandardized Coefficients } & \multirow{3}{*}{$\begin{array}{c}\text { Standardized Coefficients } \\
\text { Beta } \\
\end{array}$} & \multirow[t]{2}{*}{$\mathrm{t}$} & \multirow[t]{2}{*}{ Sig. } \\
\hline & & $\mathrm{B}$ & Std. Error & & & \\
\hline \multirow[t]{7}{*}{1} & (Constant) & .464 & .167 & & 2.783 & .006 \\
\hline & Facilities & .455 & .073 & .470 & 6.254 & .000 \\
\hline & Support & 290 & .077 & .306 & 3.778 & .000 \\
\hline & Teamwork & -.156 & .056 & -.182 & -2.775 & .006 \\
\hline & Safety & .004 & .079 & .005 & .056 & .956 \\
\hline & Stressors & .126 & .085 & .130 & 1.474 & .142 \\
\hline & Recognition & .189 & .086 & .182 & 2.183 & .030 \\
\hline
\end{tabular}

This hypothesis was tested using multiple regression analysis. With the R-Square value of 0.869 , it was confirmed that independent variables and dependent variables were strongly correlated. Again, with 
81.374 as the value of $F$ at 0.05 significant at $(0.05)$, it is confirmed that work environment had a positive effect on managerial innovation.

\subsection{2. $1^{\text {st }}$ Sub-Hypothesis}

\section{$H_{a}$ : Facilities has a positive effect on managerial innovation}

Table 11

$\mathrm{H}_{\mathrm{a}}$ Model Summary

\begin{tabular}{ccccc}
\hline Model & $\mathrm{R}$ & $\mathrm{R}$ Square & Adjusted R Square & Std. Error of the Estimate \\
\hline 1 & $.826^{\mathrm{a}}$ & .682 & .680 & .49316 \\
\hline
\end{tabular}

\section{Table 12}

$\mathrm{H}_{\mathrm{a}}$ ANOVA $^{\mathrm{a}}$

\begin{tabular}{clccccc}
\hline \multicolumn{2}{c}{ Model } & Sum of Squares & df & Mean Square & F & Sig. \\
\hline \multirow{2}{*}{1} & Regression & 85.056 & 1 & 85.056 & 349.730 & $.000^{\mathrm{b}}$ \\
\cline { 2 - 7 } & Residual & 39.642 & 163 & .243 & & \\
\cline { 2 - 7 } & Total & 124.698 & 164 & & & \\
\hline
\end{tabular}

Table 13

$\mathrm{H}_{\mathrm{a}}$ Coefficients $^{\mathrm{a}}$

\begin{tabular}{ccccccc}
\hline \multicolumn{2}{c}{ Model } & \multicolumn{2}{c}{ Unstandardized Coefficients } & Standardized Coefficients & \multirow{2}{*}{ Sig. } \\
\cline { 3 - 6 } & & $\mathrm{B}$ & Std. Error & Beta & & \\
\hline \multirow{2}{*}{1} & (Constant) & .927 & .159 & & 5.848 & .000 \\
& Facilities & .799 & .043 & .826 & 18.701 & .000 \\
\hline
\end{tabular}

This hypothesis was tested using linear regression analysis. With the R-Square value of 0.826 , it was confirmed that independent variables and dependent variables were strongly correlated. Again, with 18.701 as the value of $t$ at 0.05 significant at $(0.05)$, it is confirmed that facilities had a positive effect on managerial innovation.

\subsubsection{2ns Sub-Hypothesis}

\section{$H_{b}$ : High management support has a positive effect on managerial innovation.}

\section{Table 14}

$\mathrm{H}_{\mathrm{b}}$ Model Sumary

\begin{tabular}{ccccc}
\hline Model & R & R Square & Adjusted R Square & Std. Error of the Estimate \\
\hline 1 & $.802^{\mathrm{a}}$ & .643 & .640 & .52289 \\
\hline
\end{tabular}

Table 15

$\mathrm{H}_{\mathrm{b}}$ ANOVA $^{\mathrm{a}}$

\begin{tabular}{clccccc}
\hline \multicolumn{2}{c}{ Model } & Sum of Squares & df & Mean Square & F & Sig. \\
\hline \multirow{2}{*}{1} & Regression & 80.131 & 1 & 80.131 & 293.071 & $.000^{\mathrm{b}}$ \\
\cline { 2 - 7 } & Residual & 44.567 & 163 & .273 & & \\
\cline { 2 - 7 } & Total & 124.698 & 164 & & \\
\hline
\end{tabular}

Table 16

$\mathrm{H}_{\mathrm{b}}$ Coefficients $^{\mathrm{a}}$

\begin{tabular}{clccccc}
\hline \multirow{2}{*}{ Model } & \multicolumn{2}{c}{ Unstandardized Coefficients } & Standardized Coefficients & \multirow{2}{*}{ Sig. } \\
\cline { 3 - 6 } & \multicolumn{1}{c}{ B } & Std. Error & Beta & & \\
\hline \multirow{2}{*}{1} & (Constant) & 1.045 & .166 & & .282 & .000 \\
& support & .760 & .044 & .802 & 17.119 & .000 \\
\hline
\end{tabular}

This hypothesis was tested using linear regression analysis. With the R-Square value of 0.802 , it was confirmed that independent variables and dependent variables are strongly correlated. Again, with 17.119 
as the value of $t$-value at 0.05 significant at (0.05), it is confirmed that High management support has a positive effect on managerial innovation.

6.4.4. $3^{\text {rd }}$ Sub-Hypothesis

\section{$H_{c}$ : Teamwork has a positive effect on managerial innovation.}

Table 17

$\mathrm{H}_{\mathrm{c}}$ Model Summary

\begin{tabular}{ccccc}
\hline Model & $\mathrm{R}$ & $\mathrm{R}$ Square & Adjusted R Square & Std. Error of the Estimate \\
\hline 1 & $.532^{\mathrm{a}}$ & .283 & .279 & .74048 \\
\hline
\end{tabular}

Table 18

$\mathrm{H}_{\mathrm{c}}$ ANOVA $^{\mathrm{a}}$

\begin{tabular}{clccccc}
\hline \multicolumn{2}{c}{ Model } & Sum of Squares & df & Mean Square & F & Sig. \\
\hline \multicolumn{2}{c}{1} & Regression & 35.323 & 1 & 35.323 & 64.422 \\
& Residual & 89.375 & 163 & .548 & $.000^{\mathrm{b}}$ \\
\cline { 2 - 7 } & Total & 124.698 & 164 & & & \\
\hline
\end{tabular}

Table 19

$\mathrm{H}_{\mathrm{c}}$ Coefficients $^{\mathrm{a}}$

\begin{tabular}{|c|c|c|c|c|c|c|}
\hline \multirow{2}{*}{\multicolumn{2}{|c|}{ Model }} & \multicolumn{2}{|c|}{ Unstandardized Coefficients } & \multirow{2}{*}{$\begin{array}{c}\text { Standardized Coefficients } \\
\text { Beta }\end{array}$} & \multirow[t]{2}{*}{$\mathrm{t}$} & \multirow[t]{2}{*}{ Sig. } \\
\hline & & $\mathrm{B}$ & Std. Error & & & \\
\hline \multirow[t]{2}{*}{1} & (Constant) & 2.336 & .192 & & 12.169 & .000 \\
\hline & Teamwork & .455 & .057 & .532 & 8.026 & .000 \\
\hline
\end{tabular}

This hypothesis was tested using linear regression analysis. With the R-Square value of 0.532 , it was confirmed that independent variables and dependent variables are strongly correlated. Again, with 8.026 as the value of $t$-value at 0.05 significant at (0.05), it is confirmed that Teamwork had a positive attitude on managerial innovation.

6.4.5. $4^{\text {th }}$ Sub-Hypothesis

$H_{d}$ : Safety and security have a positive effect on managerial innovation.

Table 20

$\mathrm{H}_{\mathrm{d}}$ Model Summary

\begin{tabular}{ccccc} 
Model & $\mathrm{R}$ & $\mathrm{R}$ Square & Adjusted R Square & Std. Error of the Estimate \\
1 & $.690^{\mathrm{a}}$ & .476 & .472 & .63333 \\
\hline
\end{tabular}

\section{Table 21}

$\mathrm{H}_{\mathrm{d}}$ ANOVAa

\begin{tabular}{clccccc}
\hline \multicolumn{2}{l}{ Model } & Sum of Squares & df & Mean Square & F & Sig. \\
\hline \multirow{2}{*}{1} & Regression & 59.319 & 1 & 59.319 & 147.889 & $.000^{\mathrm{b}}$ \\
\cline { 2 - 7 } & Residual & 65.380 & 163 & .401 & & \\
\cline { 2 - 7 } & Total & 124.698 & 164 & &
\end{tabular}

Table 22

$\mathrm{H}_{\mathrm{d}}$ Coefficients $^{\mathrm{a}}$

\begin{tabular}{|c|c|c|c|c|c|c|}
\hline \multirow{2}{*}{\multicolumn{2}{|c|}{ Model }} & \multicolumn{2}{|c|}{ Unstandardized Coefficients } & \multirow{2}{*}{$\begin{array}{c}\text { Standardized Coefficients } \\
\text { Beta }\end{array}$} & \multirow[t]{2}{*}{$\mathrm{t}$} & \multirow[t]{2}{*}{ Sig. } \\
\hline & & $\mathrm{B}$ & Std. Error & & & \\
\hline \multirow[t]{2}{*}{1} & (Constant) & 1.771 & .174 & & 10.151 & .000 \\
\hline & Safety & .614 & .051 & .690 & 12.161 & .000 \\
\hline
\end{tabular}

This hypothesis was tested using linear regression analysis. With the R-Square value of 0.69 , it was confirmed that independent variables and dependent variable were strongly correlated. Again, with 
12.161 as the value of $t$-value at 0.05 significant at (0.05), it is confirmed that Safety and Security had a positive attitude on managerial innovation.

\subsection{6. $5^{\text {th }}$ Sub-Hypothesis}

\section{$H_{\mathrm{e}}$ : Work stressors have a positive effect on managerial innovation.}

Table 23

$\mathrm{H}_{\mathrm{e}}$ Model Summary

\begin{tabular}{lcccc}
\hline Model & R & R Square & Adjusted R Square & Std. Error of the Estimate \\
\hline 1 & $.715^{\text {a }}$ & .512 & .509 & .61107 \\
\hline
\end{tabular}

Table 24

$\mathrm{H}_{\mathrm{e}}$ ANOVAa

\begin{tabular}{clccccc}
\hline \multicolumn{2}{l}{ Model } & Sum of Squares & df & Mean Square & F & Sig. \\
\hline \multirow{2}{*}{1} & Regression & 63.833 & 1 & 63.833 & 170.947 & $.000^{\mathrm{b}}$ \\
\cline { 2 - 7 } & Residual & 60.866 & 163 & .373 & & \\
\cline { 2 - 7 } & Total & 124.698 & 164 & &
\end{tabular}

Table 25

$\mathrm{H}_{\mathrm{e}}$ Coefficients $^{\mathrm{a}}$

\begin{tabular}{|c|c|c|c|c|c|c|}
\hline \multirow{2}{*}{\multicolumn{2}{|c|}{ Model }} & \multicolumn{2}{|c|}{ Unstandardized Coefficients } & \multirow{2}{*}{$\begin{array}{c}\text { Standardized Coefficients } \\
\text { Beta }\end{array}$} & \multirow[t]{2}{*}{$\mathrm{t}$} & \multirow[t]{2}{*}{ Sig. } \\
\hline & & $\mathrm{B}$ & Std. Error & & & \\
\hline \multirow[t]{2}{*}{1} & (Constant) & 1.257 & .201 & & 6.263 & .000 \\
\hline & Stressors & .695 & .053 & .715 & 13.075 & .000 \\
\hline
\end{tabular}

This hypothesis was tested using linear regression analysis. With the R-Square value of 0.715 , it was confirmed that independent variables and dependent variable were strongly correlated. Again, with 13.075 as the value of $t$-value at 0.05 significant at $(0.05)$, it is confirmed that Work stressors had a positive effect on managerial innovation.

\subsection{7. $6^{\text {th }}$ Sub-Hypothesis}

$\mathrm{H}_{\mathbf{f}}$ : Recognition and appreciation have a positive effect on managerial innovation.

Table 26

$\mathrm{H}_{\mathrm{f}}$ Model Summary

\begin{tabular}{ccccc}
\hline Model & R & R Square & Adjusted R Square & Std. Error of the Estimate \\
\hline 1 & $.676^{\mathrm{a}}$ & .458 & .454 & .64419 \\
\hline
\end{tabular}

Table 27

$\mathrm{H}_{\mathrm{f}}$ ANOVA $^{\mathrm{a}}$

\begin{tabular}{clccccc}
\hline \multicolumn{2}{c}{ Model } & Sum of Squares & df & Mean Square & F & Sig. \\
\hline \multirow{2}{*}{1} & Regression & 57.056 & 1 & 57.056 & 137.490 & $.000^{\mathrm{b}}$ \\
\cline { 2 - 7 } & Residual & 67.642 & 163 & .415 & & \\
\cline { 2 - 7 } & Total & 124.698 & 164 & & \\
\hline
\end{tabular}

Table 28

$\mathrm{H}_{\mathrm{f}}$ Coefficients $^{\mathrm{a}}$

\begin{tabular}{clccccc}
\hline \multirow{2}{*}{ Model } & \multicolumn{2}{c}{ Unstandardized Coefficients } & Standardized Coefficients & \multirow{2}{*}{ Sig. } \\
\cline { 3 - 6 } & & $\mathrm{B}$ & Std. Error & Beta & & \\
\hline \multirow{2}{*}{1} & (Constant) & 1.288 & .220 & & 5.840 & .000 \\
& Recognition & .702 & .060 & .676 & 11.726 & .000 \\
\hline
\end{tabular}

This hypothesis was tested using linear regression analysis. With the R-Square value of 0.676 , it was confirmed that independent variables and dependent variable were strongly correlated. Again, with 
11.726 as the value of $t$-value at 0.05 significant at (0.05), it is confirmed that Recognition and appreciation had a positive effect on managerial innovation.

\subsection{Major Findings and Discussion}

Based on the analysis of the current study and the hypotheses; it is inferred that the main hypothesis was acceptable and there was a positive influence of work environment on managerial innovation among managers and leaders within the insurance sector in Kuwait. Additional findings are as follows:

1- Results indicated that the insurance sectors in Kuwait, according to the sample answers, had the needed awareness of work environment meaning and constituents. In addition to that, the sample knew what managerial innovation means and managed to agree on the statements that matched their circumstances.

2- According to the demographic results of study, the feminine influence was apparent, given that, the majority of respondents who answered the questionnaire were female employees. It also highlights the empowerment in Kuwait, given to females and their abilities to hold managerial positions.

3- Through the variables of the study analysis, it has appeared that the most influential variable of work environment on managerial innovation was facilities with an R-Square value of .826; which revealed the influence of facilities on having a healthy work environment on employees and enhance their abilities to perform well. However, this variable was followed with a powerful variable to influence, which is, higher management support with an R-Square value of .802 referring to the role of higher management support in building a work environment that is suited for individuals in the organizations.

4- The least influential variable through the analysis was teamwork which R-Square value of .532 referring to it as the least influential factor on managerial innovation. This indicated the lack of teamwork concept within the insurance sector in Kuwait. Looking at the nature of the results appeared that work environment influences many aspects within the organization including the degree of job satisfaction, performance and managerial innovation.

One of the essential principles in key administration is that innovation can enable organizations to outdo their competitors. While innovation is obviously a standout amongst the most usually tended to subjects in management and scholarly distributions alike explore has by and large moved toward development as the improvement of new items, innovation or administrations. Subsequently, managerial innovation has been dominating in development, exploration, with related ideas, for example, item improvement, radical versus incremental innovation, and in addition, dispersion and appropriation accepting a great deal of consideration. Firms may search for different territories to develop different methods for picking up and keeping up a focused edge. This would involve a search for new items and new innovations, as well as for changes in the ideas of administration inside the association, i.e. managerial innovation. Management innovation refers to what supervisors do and how they do it, featuring the activities of a focal performer, to be specific the director. While the precise investigation of managerial innovation has, of late, risen in the writing, occurrences of the marvel and its potential advantages to associations, possess large amounts of various written works. When talking about what motivates managers and leaders to be creative, we talk about the environment in which they work. Having an environment that is supportive for innovation is the key principle in reaching a stage where employees, regardless of their positions, have the ability to be more innovative in many aspects within the organizations. This includes practices, strategies, planning, mission, vision and decision making process. Results of study matched with many other studies which examined the positive role that work environment plays in an organization. It has a lot of benefits in terms of encouraging the performance of individuals and having them understand what their organization is looking for when it comes to their performance. These results were in total agreement with the results of the following studies (Dufays, 2018; Soto-Acosta \& Martinez-Conesa, 2018; Lerro et al., 2014; Buenechea-Elberdin et al., 2018; Su \& Baird, 2017). In addition, there are many studies within the literature which see work environment as a crucial idea that has the ability to drive the organization towards 
the success, among these studies Barsh et al. (2008) who argued that innovation must be accompanied with a healthy work environment, and Sánchez et al. (2011) who stated that positive work place can motivate the way innovation roams around within the organization. Also there is an agreement with Dul and Ceylan's (2011) study, who spoke of work environment as the first and effective driver of organization's innovation. In addition to Serrat (2017) and Szobiová (2015) who both agreed that a healthy work environment has the ability to induce innovation and creativity among employees in the organization.

\section{Conclusion}

Innovation in management has been considered both as a discrete result and as a procedure. Innovation as a procedure needs a place where it can be diffused and employed. In order to guarantee the best and most beneficial innovative application within the organization there should be a place that has the ability to understand and embrace such as a suitable approach of thinking. In addition, the culture of change management and change acceptance should be found within the members of the organization. When looking at the definition of innovation it can be seen that it is: coming up with new ideas and approaches to get things done. When innovation is prescribed/planned by the management, it has to be accepted and applied by the followers and employees. From that point they should have the ability to embrace such change in a good work environment that is able to support such creativity.

\section{Recommendations}

From the analysis and discussion of the results, the current study recommends organizations to put extra attention to some factors of employee appraisal such as incentives, appreciation and recognition, that may boost the degree of managerial innovations. Insurance organizations in Kuwait are recommended to increase the focus on the concept of teamwork and its importance among employees as it appeared to be the least influential factor among the sample. It is recommended to examine the influence of work environment on the ethical orientations among leaders within the insurance sector in Kuwait.

\section{References}

Ajala, E.M. (2012). The influence of workplace environment on workers' welfare, performance and productivity. The African Symposium, 12(1), 141-149.

Al-Mshoot, M. (2011). The impact of work environment on managerial innovation within Saad Al-Abdullah academy for security sciences in Kuwait state. MA thesis, Middle East University - Amman - Jordan

Al-Omari, K., \& Okasheh, H. (2017). The Influence of Work Environment on Job Performance: A Case Study of Engineering Company in Jordan. International Journal of Applied Engineering Research, 12(24), 1554415550

Awamleh, N. I. A. (1994). Managerial innovation in the civil service in Jordan: A field study. Journal of Management Development, 13(9), 52-60.

Bannon, E. (2010). The Effectiveness Of An Acceptance And Commitment Therapy Intervention For Work Stress On Innovation (Doctoral dissertation, Bowling Green State University).

Barsh, J., Capozzi, M. M., \& Davidson, J. (2008). Leadership and innovation. McKinsey Quarterly, 1, 36.

Bryson, A., Dale-Olsen, H., \& Barth, E. (2009). How does innovation affect worker well-being?. Center for economic performance, 1-23.

Buenechea-Elberdin, M., Kianto, A., \& Sáenz, J. (2018). Intellectual capital drivers of product and managerial innovation in high-tech and low-tech firms. R\&D Management, 48(3), 290-307.

Caniëls, M., Kooistra, W. and Semeijn, J. (2008). Drivers and obstacles for innovation in logistics. In The 5th International Conference on Innovation \& Management. Google Scholar.

Chang, Y. Y. (2016). Multilevel transformational leadership and management innovation: Intermediate linkage evidence. Leadership \& Organization Development Journal, 37(2), 265-288.

Damanpour, F., \& Aravind, D. (2012). Managerial innovation: Conceptions, processes and antecedents. Management and Organization Review, 8(2), 423-454.

Dawson, P. M., \& Zanko, M. (2009). Innovative workplace change: social well-being and health.

De Spiegelaere, S., Van Gyes, G., De Witte, H., Niesen, W., \& Van Hootegem, G. (2014). On the relation of job insecurity, job autonomy, innovative work behaviour and the mediating effect of work engagement. Creativity and Innovation Management, 23(3), 318-330. 
Dul, J., \& Ceylan, C. (2011). Work environments for employee creativity. Ergonomics, 54(1), 12-20.

Foldspang, L., Mark, M., Hjorth, L. R., Langholz-Carstensen, C., Poulsen, O. M., Johansson, U., ... \& Rants, L. L. (2014). Working environment and productivity: A register-based analysis of Nordic enterprises. Nordic Council of Ministers.

Garr, S. (2012). The state of employee recognition in 2012. Oakland, CA: Bersin and Associates.

Gilbride, D., Stensrud, R., Vandergoot, D., \& Golden, K. (2003). Identification of the characteristics of work environments and employers open to hiring and accommodating people with disabilities. Rehabilitation Counseling Bulletin, 46(3), 130-137.

Hawley, J. D., \& Barnard, J. K. (2005). Work environment characteristics and implications for training transfer: A case study of the nuclear power industry. Human Resource Development International, 8(1), 65-80.

Ismaeil, M. (2014). The Influence of Work Environment on Managerial Innovation. MA thesis, Sudan University of Science and Technology (SUST) - Sudan

Kroth, M., Boverie, P., \& Zondlo, J. (2007). What managers do to create healthy work environments. Journal of Adult Education, 36(2), 1-12.

Lerro, A., Linzalone, R., \& Schiuma, G. (2014). Managing intellectual capital dimensions for organizational value creation. Journal of Intellectual Capital, 15(3), 350-361.

Nieves, J., \& Osorio, J. (2018). Using information technology to achieve management innovation. Academia Revista Latinoamericana de Administración.

Nurmandi, A., \& Kim, S. (2015). Making e-procurement work in a decentralized procurement system: A comparison of three Indonesian cities. International Journal of Public Sector Management, 28(3), 198-220.

Pot, F. (2011). Workplace innovation for better jobs and performance. International Journal of Productivity and Performance Management, 60(4), 404-415.

Rosario Perello-Marin, M., Marin-Garcia, J. A., \& Marcos-Cuevas, J. (2013). Towards a path dependence approach to study management innovation. Management Decision, 51(5), 1037-1046.

Sánchez, A., Lago, A., Ferràs, X., \& Ribera, J. (2011). Innovation management practices, strategic adaptation, and business results: evidence from the electronics industry. Journal of Technology Management \& Innovation, 6(2), 14-39.

Sanyal, S., \& Hisam, M.W., (2018) The Impact of Teamwork on Work Performance of Employees: A Study of Faculty Members in Dhofar University.

Serrat, O. (2017). Harnessing creativity and innovation in the workplace. In Knowledge Solutions (pp. 903-910). Springer, Singapore.

Shobe, K. (2018). Productivity driven by job satisfaction, physical work environment, management support and job autonomy. Business and Economics Journal, 9(2), 2-9

Smith, W. K., \& Tushman, M. L. (2005). Managing strategic contradictions: A top management model for managing innovation streams. Organization Science, 16(5), 522-536.

Soto-Acosta, P., Popa, S., \& Martinez-Conesa, I. (2018). Information technology, knowledge management and environmental dynamism as drivers of innovation ambidexterity: a study in SMEs. Journal of Knowledge Management, 22(4), 824-849.

Stansfeld, S., \& Candy, B. (2006). Psychosocial work environment and mental health-a meta-analytic review. Scandinavian Journal of Work, Environment \& Health, 32(6), 443-462.

$\mathrm{Su}, \mathrm{S}$., \& Baird, K. (2017). The role of leaders in generating management innovation. The International Journal of Human Resource Management, 1-22. https://doi.org/10.1080/09585192.2017.1282533

Szobiová, E. (2015). Creativity in organizational environment. Acta Technologica Dubnicae, 5(2),69-79.

Ying, S.R. (2006). Creating Supportive Environment for Innovation: A Conceptual Model Study.

Zlatanović, D., \& Mulej, M. (2015). Soft-systems approaches to knowledge-cum-values management as innovation drivers. Baltic Journal of Management, 10(4), 497-518.

Zúñiga, F., Ausserhofer, D., Hamers, J. P., Engberg, S., Simon, M., \& Schwendimann, R. (2015). The relationship of staffing and work environment with implicit rationing of nursing care in Swiss nursing homes-A crosssectional study. International Journal of Nursing Studies, 52(9), 1463-1474.

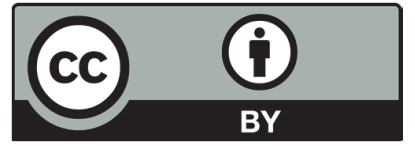

(C) 2019 by the authors; licensee Growing Science, Canada. This is an open access article distributed under the terms and conditions of the Creative Commons Attribution (CCBY) license (http://creativecommons.org/licenses/by/4.0/). 